\title{
Kernos
}

Revue internationale et pluridisciplinaire de religion grecque antique

31 | 2018

Varia

\section{Regionality and Greek Ritual Norms}

\section{Robert Parker}

\section{OpenEdition \\ Journals}

\section{Electronic version}

URL: http://journals.openedition.org/kernos/2678

DOI: $10.4000 /$ kernos. 2678

ISSN: 2034-7871

\section{Publisher}

Centre international d'étude de la religion grecque antique

\section{Printed version}

Date of publication: 1 December 2018

Number of pages: 73-81

ISBN: 978-2-87562-055-2

ISSN: 0776-3824

\section{Electronic reference}

Robert Parker, "Regionality and Greek Ritual Norms", Kernos [Online], 31 | 2018, Online since 01

October 2020, connection on 25 January 2021. URL: http://journals.openedition.org/kernos/2678 ;

DOI: https://doi.org/10.4000/kernos.2678

This text was automatically generated on 25 January 2021.

Kernos 


\title{
Regionality and Greek Ritual Norms
}

\author{
Robert Parker
}

1 Most scholars, if discussing a Greek Ritual Norm (henceforth GRN), will cite parallels from all other GRN whatever their origin: they are, that is to say, treated as a homogeneous corpus, without geographical differentiation. ${ }^{1}$ It is surely worth asking the question whether this homogeneity is a reality. There are in fact two interrelated questions here: one is about uniformity or lack of it within old Greek communities, the second about the spread of GRN into regions that were not by origin Greek; and one might add a third, the spread of foreign norms within "old Greece". I take one example of how a geographic perspective on GRN is important. Collection of Greek Ritual Norms ${ }^{2}$ (henceforth CGRN) 97 is entitled "Fragmentary regulation concerning a female

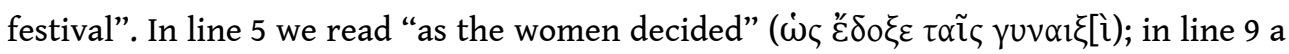
male person is required to depart after doing something in regard to hiera (] $\xi \alpha_{\alpha} \mu \varepsilon v o \varsigma$

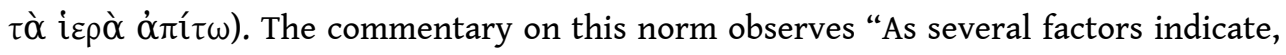
this occasion might be identified with, or at least likened to, the Thesmophoria." This was in fact the text used by Marcel Detienne to argue that, even at women's festivals, a male was present to perform the sacrificial killing: he strikes the blow, and then leaves. ${ }^{3}$ So far so good, but what needs to be stressed is that this text comes from Mylasa in inland Caria and is dated from letter forms to the second half/late $4^{\text {th }} \mathrm{C} . \mathrm{BC} .{ }^{4}$ It is a commonplace that Caria under the Hekatomnids and in the early Hellenistic period was adopting many aspects of Greek culture. But what CGRN 97 seems to attest goes far deeper than, say, employing a Greek architect. The Thesmophoria is not a festival that can be casually imported: it implies a whole organisation of society. Crucial aspects of the Greek way of life, for both sexes, have arrived in Mylasa if the interpretation is sound. ${ }^{5}$

2 This question about the geography of GRN is large and neglected: I merely take here some hesitant first steps. If differences emerge, it will be important to ask whether they are a product of difference in ritual practice or merely difference in epigraphic habit. On Rhodes, and almost there only, ${ }^{6}$ extracts from a broader sacrificial calendar were displayed in the sanctuary where actual sacrifice was to be made. This is a difference in epigraphic habit; the difference itself needs to be explained, but the explanation will 
probably be at the level of political organisation rather than of ritual practice. Again, there seems to have been no inscribed purity law in Attica until the slave Xanthos added some to his private cult of Men in the second century AD (LSCG 55). Many more GRN survive from Attica than anywhere else, so the absence is unlikely to be due to the chances of preservation. Literary sources (e.g. Eur. IT 381-383; Dem. 22.78) make it inconceivable that no purity restrictions existed, so we are surely dealing with a matter of epigraphic habit. A question remains why it was not felt necessary to record the conventions on stone: was there a tradition of proclamations, of oral exegesis? ${ }^{7}$

In respect of GRN, some regions are virtual deserts. Thessaly offers three in Sokolowski (1969), but they concern the broad organisation of festivals, not ritual details, and so fail to meet the different admission criteria of CGRN. The situation changed drastically with the publication in Kernos 2015 of an enormous text found at Marmarini regulating a hitherto unknown mystery cult. ${ }^{8}$ But that text is a true one off, and it remains the case that Thessaly lacks GRN of more normal types. Sicily and Italy, even if we combine Sokolowski (1962) and CGRN, offer just two, both exceptional: an eight-word text from Cumae allowing no one to be buried in a particular place unless initiated to Bacchos (LSS 120), and the famous bronze from Selinus that prescribes, amid much else, how to get free by purification from elasteroi (CGRN 13). Central Anatolia, the whole world covered by LGPN VC, offers as far as I know no single GRN. This again is partly a question of epigraphic habit: inscriptions from Central Anatolia only become common in the Roman imperial period, just when GRN in general become less common, but it surely also tells us something about the different religious environment of, let us say, the village world of Phrygia. Egypt has one GRN, Syria none.

4 If one looks at particular categories of document, great unevennesses again emerge. Take sacrificial calendars for instance, as helpfully listed in CGRN: there are archaic examples from Corinth, Gortyn, Miletus and now Arcadia, but after that almost everything comes from a tiny range of sites: Attica, Rhodes (all the excerpts mentioned above), and Cos. There are just a handful of outliers which are mostly easy to explain: a rupestral inscription from Thera which treats a single dated event, and so scarcely qualifies as a calendar (CGRN 47); the calendar published on Mykonos after the synoecism, the motivating factor for which, the changes caused by the synoecism, is obvious (CGRN 156); and what looks like a true calendar from Eleutherna in Crete of the second century BC, for which by contrast no ready explanation offers itself (CGRN 210). Another outlier, a fourth-century calendar found at Miletupolis on the southern shore of the Propontis (CGRN 83) raises an interesting question. The first editor Schwertheim took certain strikingly Attic elements in the text, above all the month name Skirophorion, as evidence that Miletupolis had been founded or re-founded under Attic influence c. $410 \mathrm{BC}$, while Habicht even suggested that it might be a pierre errante from Attica. That conclusion has been challenged, ${ }^{9}$ but the facts about the distribution of calendars just noted might be used to support Habicht's position: at this time and place the calendar looks isolated. On the other hand, if we accept with Schwertheim that the local calendar was re-modelled under Attic influence, we can suppose that the calendar-making habit came in from there too. Perhaps the isolation can be exaggerated anyway: a recently published early hellenistic (?) decree of the boule from nearby Kyzikos introduces what looks like a month-by-month calendar. ${ }^{10}$

5 So much for absences, places that do not offer GRN at all or not of particular types. I turn now, from texts that do not exist, to those that do, and would like to suggest a 
thought experiment. If we pretend that a particular text had come to us on the antiquities market without provenance and without internal evidence for provenance (such as dialect, or locally specific theonyms or festival names), would we able to locate it in space on the evidence of the ritual norms contained in it alone? Of the types of text distinguished in CGRN, three that are particularly susceptible to such an approach are those relating to priesthoods, to sacrificial perquisites, and to purity. I start with priesthoods. Here there is one clear regional differentiation to grasp. It is well known that on the islands of the eastern Aegean and in Asia Minor, the practice of the sale of priesthoods was common though not universal; it is unknown on the mainland (with the exception of one late case in a private society, LuPu [2005], no. 5). The westernmost point where it appears is Andros. So, a document regulating a priesthood sale must come from Andros or a place further east. The converse does not apply: even in the priesthood-selling regions, not all cities sold their priesthoods (Cos did, Rhodes did not, for instance), and even in some and perhaps all cities where some priesthoods were sold, not all were so treated. ${ }^{11}$ We know from an oracular enquiry made by Heracleia under Latmos that the decision whether to sell a priesthood could come before the civic assembly and be put to an oracle. ${ }^{12}$ So a document regulating a priesthood that is not for sale does not necessarily come from a place west of Andros. Among texts concerning sales of priesthoods one further sub-division is worth noting. Some such texts seek to guarantee the priest an income by requiring members of certain professions to sacrifice in the cult: this rule seems to be confined to the island of $\operatorname{Cos} .^{13}$

There are two texts concerning priesthoods of which we might have said, if they had lacked a provenance, that, though they cannot be located, they must certainly derive from a place or time different from all the others. One is the famous fourth-century trilingual stele from Xanthos (CGRN 93) which sets up a permanent hereditary priesthood of Basileus Kaunios and provides an endowment of land and taxation income to finance the priesthood and the cult. The Greek of this text is rather curious, translationese in fact, but the content too is unusual: the financing of the cult from land and tax finds parallels in the Greek world (though mostly later), but such a public endowment in favour of a named individual and his descendants appears unique. Another text without parallel is one from the Galatian settlement at Pednelissos in Pisidia which deals with the priestess known as Galato (CGRN 213): Galato is presumably a standard name attaching to any priestess of the cult, like Atthis, not a personal name. 14 "On the whole, the document bears some similarities with other Greek ritual norms, but is also remarkably different in its specific prescriptions and ritual details", state the commentators on this text in CGRN: most obviously, it lays down how she is to be mourned for after death. In both these cases one might say we are dealing with ritual norms written in Greek rather than Greek ritual norms. ${ }^{15}$

7 I turn now to purity. CGRN lists 24 texts as purity regulations; a fine new specimen from Thyateira has just come to join them. ${ }^{16}$ The first seven predate $350 \mathrm{BC}$ and are diverse; the rest play variations on the theme of "enter pure from" various conditions. Similar though they mostly are, no two are identical; they thus illustrate broadly shared concerns, but also the absence of authoritative panhellenic norms about the precise extent of particular pollutions. Ivana and Andrej Petrovic have pointed out that, where such texts specify the number of days of abstention to be observed, they either come from the islands or Asia Minor, not mainland Greece, or regulate the cult of non-Greek gods. ${ }^{17}$ For the reasons already mentioned in relation to Attica, that distinction must be one of epigraphic convention rather than practice: contact with certain conditions 
certainly created impurity on the mainland too, for periods that cannot have been left completely vague ${ }^{18}$ All the same, the Petrovics' observation provides one rule of thumb for my thought experiment. But their point that the cult of (e.g.) an Egyptian god may attract explicit "enter pure from" rules even on the mainland suggests that the identity of the god worshipped is a determinant that can overrule local epigraphic convention. The public display of purity rules apparently matters more in some cults than others, and the deity involved also affects the content of the rules. Menstruation, for instance, pollutes in the cult of certain non-Greek gods (Men and Isis) even when they come to Greece, ${ }^{19}$ it does not (with perhaps one exception on Rhodes) pollute in the cult of Greek gods even when they move to the islands or Anatolia. Another determinant is date. New pollutions appear, and periods of exclusion tend to get longer, ${ }^{20}$ in later texts. The only regional specificities I have noted, beyond the broad "mainland Greece vs the rest" of the Petrovics, are rather minor: defloration only pollutes in two late norms both from Lindos, a hetaira requires purification before entering a shrine only in two hellenistic texts from Lydia. ${ }^{21}$ These are perhaps local variations, but within a type of text that is much more broadly distributed. Here too I will mention two outliers. One is the famous set of purity laws from Cyrene which adds to the usual pollutions both

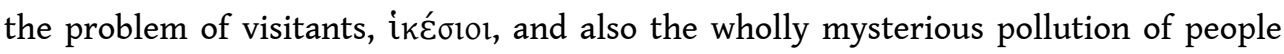

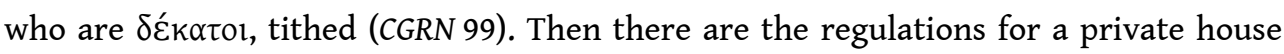
cult set up at Philadelphia in Lydia by one Dionysios (CGRN 191). This text goes against all the norms: it ignores all the involuntary pollutions caused by contact with birth and death, concentrating instead on moral transgressions; anyone guilty of such transgressions it excludes from the shrine not for a few days but in perpetuity. Both texts are extraordinary in their different ways. That from Cyrene does perhaps attest a ritual condition, that of $\delta \varepsilon \dot{k} \alpha \tau \tau$, specific to Cyrene; the Philadelphia text is an individual's attempt to redefine "enter pure from" rules so as to embody the region's highest moral ideals. ${ }^{22}$

There remains the large and central topic of sacrifice; I would not have ventured to tackle this without the aid of a recent article by Carbon (2017) which treats it with great expertise and addresses the possibility of regional variation explicitly. GRN, unfortunately, are not concerned to give us a picture of how sacrifice was performed; in the majority of cases, their business is to define the perks due to priests, and so this perforce is what we must concentrate on. Carbon begins by noting a common feature: the minimum received by the priest is almost always the skin of the animal, and a leg. ${ }^{23}$ But he goes on to present a bewildering range of variations: partly at the level of vocabulary, because many expressions occur only once or twice and are hard for us to pin down, but also at the substantive level: front leg, back leg, left leg, right leg, what exactly is a leg?, and much more too. It may seem at first sight that we are faced, as with purity laws, with a series of more or less inexplicable variations on a common theme. But he then takes three places where we have quite extensive evidence Athens, Miletus, Chios - and points out that the lists of perks from these typically differ. At Athens the norm is "a leg or thigh, followed by either a side of rib or a side of hip and finally, in most cases, a part of the head", whereas in three texts from Miletus

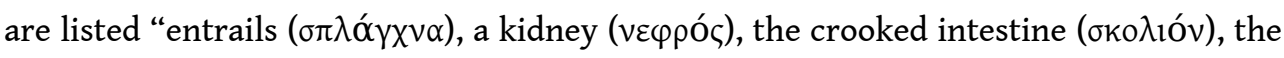

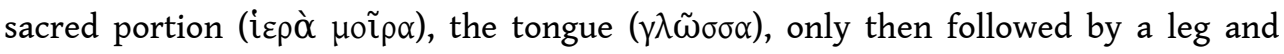
perhaps other portions." Chios tends in the direction of Miletus, though not invariably; indeed even Miletus does not always respect its own norms. In terms of my thought experiment, this is another success, one of few. We can recognise a characteristic, if not 


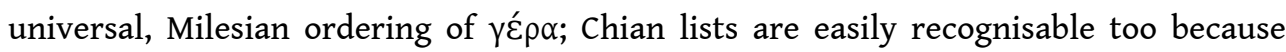

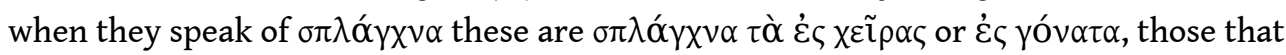
go onto the knees or into the hands of statues. ${ }^{24}$

9 After carefully establishing these distinctions, Carbon goes on to argue that they can be explained in terms of epigraphic habit rather than actual ritual practice. He suggests that in Athens the principle of listing the үर́ $\rho \alpha$ is "best first", so starting with the leg, whereas in the east it reflects the process of butchery: first you extract the entrails, while the leg is among the last portions cut. But it is not just the order that varies, but also the content. To keep the issue simple, I will pick out one notable difference: the

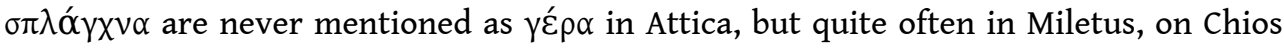
and indeed elsewhere in Asia Minor. In standard accounts of sacrifice in modern books it is said that the $\sigma \pi \lambda \alpha \gamma_{\gamma \chi} \alpha \alpha$ were distributed for immediate eating among the inner

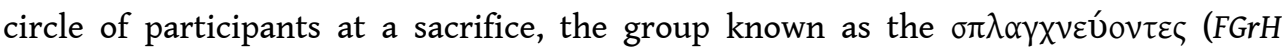
356 F 1) or $\sigma 0 \sigma \pi \lambda \alpha \gamma \chi v \varepsilon v ́ o v \tau \varepsilon \zeta$ (Ar. Pax 1115). So they are for communal consumption, and do not go to the priest except as one among the participants. The Attic evidence fits that model: they are absent from the list of priestly perks. But what then do we say about Miletus and other places, where $\sigma \pi \lambda \alpha^{\prime} \gamma \chi \chi \alpha$ do go to the priest? An answer can perhaps be given to that question. We can suppose that the $\sigma \pi \lambda \alpha^{\prime} \gamma \chi v \alpha$ assigned to the priest in the Milesian texts are not all the $\sigma \pi \lambda \alpha^{\prime} \gamma \chi \chi \alpha$ but the customary portion of them: in texts from Iasos and Halicarnassus, the priest in fact gets a quarter share, $\tau \varepsilon \tau \alpha \rho \tau \eta \mu о \rho i ́ \varsigma, ~ o f ~ \sigma \pi \lambda \alpha^{\prime} \gamma \chi v \alpha,{ }^{25}$ which would leave a respectable amount for general consumption. Equally, no text proves that where communal consumption by the

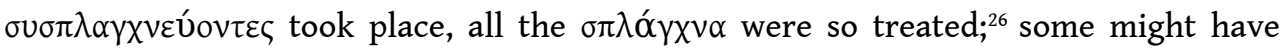
remained for the priest even in Attica (though admittedly not so mentioned). ${ }^{27}$ If so, Carbon's argument can stand that what differs is the convention for listing the $\gamma \varepsilon \dot{\varepsilon} \rho$, not, much more drastically, the actual sacrificial practice.

Here too there is one outlier to be mentioned, the extraordinary new text from Marmarini, ${ }^{28}$ which offers a kind of sacrificial menu: if anyone wishes to perform this or that kind of offering, then let him... nine possibilities are listed in all. But here again we are dealing not so much with a GRN as with a complicated mixture of Greek and Semitic norms, written in Greek.

Clear and systematic regional divisions in actual ritual norms, as opposed to epigraphic habit and vocabulary, have not emerged. A real difference exists in regard to the sale of priesthoods, but that is not a ritual norm. Some texts are one off, unique; among those unique texts, a few seem to reflect non-Greek norms written in Greek, but texts even from regions which adopted Greek quite late seem mostly also to have adopted Greek norms. From the less hellenised regions of Anatolia we have in the main, not exotic ritual norms, but silence. This absence of regional distinctions is rather noteworthy. It is a cliché to point out that every city in the Greek world honours a somewhat different selection of gods and heroes. But the case seems to differ when we look at GRN governing sacrifice and purity. At this level there is perhaps something we can call Greek religion. 


\section{BIBLIOGRAPHY}

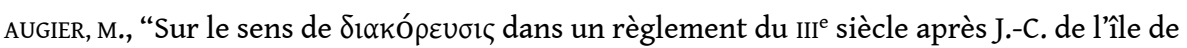
Rhodes", RPh 87 (2013), p. 27-36.

-, "Le sang menstruel dans les prescriptions cathartiques", in L. BODIOU, V. MEHL (eds.), La Grèce écarlate. Le sang des Anciens, Rennes, 2017, p. 95-112.

BOUCHON, R., and DECOURT, J.-C., "Le règlement religieux de Marmarini (Thessalie) : nouvelles lectures, nouvelles interpretations”, Kernos 30 (2017), p. 159-186.

CARBON, J.-M., “A Hellenistic Ritual Calendar from Kyzikos”, EA 47 (2014), p. 149-155.

-, "Meaty Perks: Epichoric and Topological Trends", in S. HITCH, I. RUTHERFORD (eds.), Animal Sacrifice in the Ancient Greek World, Cambridge, 2017, p. 151-178.

CARBON, J.-M., and PIRENNE-DELFORGE, V., “Beyond Greek « Sacred Laws »”, Kernos 25 (2012), p. 163-182.

DETIENNE, M., “" Violentes eugénies » : en pleines Thesmophories des femmes couvertes de sang”, in M. DETIENNE, J.-P. VERNANT (ed.), La cuisine du sacrifice en pays grec, Paris, 1979, p. 183-214.

DE HOZ, M.P., "The Regulations of Dionysius in the so-Called Lex Sacra from Philadelphia in Lydia", EA 50 (2017), p. 93-108.

LUPU, E., Greek Sacred Law, Leiden, 2005.

MALAY, H., and PETZL, G., New Religious Texts from Lydia, Vienna, 2017.

PARKER, R., Miasma. Pollution and Purification in Early Greek Religion, Oxford, 1983.

-, Polytheism and Society at Athens, Oxford, 2005.

PARKER, R. and OBBINK D., "Sales of Priesthoods on Cos I", Chiron 30 (2000), p. 416-447.

PARKER, R. and THONEMANN, P., “A Hellenistic Sale of a Priesthood from Halikarnassos”, ZPE 194

(2015), p. 132-134.

PETROVIC, I. and PETROVIC, A. (2018), "Purity of Body and Soul in the Cult of Athena Lindia: On the Eastern Background of Greek Abstentions”, in J.M. CARBON, S. PEELS-MATTHEY (ed.), Purity and Purification in the Ancient Greek World, Liège, 2018, p. 225-260.

SокоLоWsкI, F., Lois sacrées des cités grecques. Supplément, Paris, 1962.

-, Lois sacrées des cités grecques, Paris, 1969.

\section{NOTES}

1. This article derives from my contribution to the colloquium "Autorité, normes et rituels en Grèce ancienne," organised at the Collège de France on May 22-23. I am grateful to the audience for comments, and in particular to Jan-Mathieu Carbon for much advice before the event, and for most helpful observations on a draft after it.

2. http://cgrn.ulg.ac.be/

3. DETIENNE (1979).

4. The original editors, and BLÜMEL on I.Mylasa 303, took the text as a later hellenistic copy of a fourth-century document; this view is rejected as unnecessarily complicated in CGRN. 
5. Angelos Chaniotis reminds me of the recent attestation of a Thesmophorion at Limyra in Lycia in the first years of the second c. BC: SEG 61, 1236. 11. And Carbon adds the appearance of the month name Thesmophorion in hellenistic Caria: at Amyzon (I.Amyzon 14) and Herakleia Latmia (RPh 23 [1899], p. 284-86, no. 7 and Milet I.3 150, 54-55), which is, however, less decisive.

6. See CGRN 63,109, with commentaries. An unpublished inscription from Cos is similar; note too CGRN 47, from Thera, and the much more extensive but still selective CGRN 151 from Halasarna on Cos.

7. For Attic proclamations on related topics Carbon refers me to the laws cited at [Dem.] 43.57:

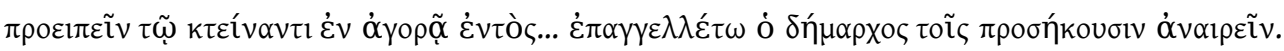
Note too Eur.IT 1226-1229. Carbon also points out that in the fifth-century funerary laws of Iulis on Ceos, CGRN 35, generally thought to be based on those of Solon, purity requirements become explicit (but negatively - to restrict the scope and duration of pollutions).

8. Now to be read in BOUCHON - DECOURT (2017).

9. By PARKER (2005), p. 484-485; HAMON, BÉ (2015), no. 597; the editors of CGRN 83.

10. See CARBON (2014). Carbon does not accept the tentative suggestion of Hamon, BÉ (2015), no. 597, that the Kyzikos and Miletupolis texts might actually belong to the same stone; his reasons will appear in SEG 64 .

11. For Halicarnassus and Cos, see PARKER -THONEMANN (2015).

12. SEG $40,956$.

13. See PARKER -OBBINK (2000), p. 427-429.

14. Pace LGPN V.C, which lists it as a name.

15. Another Pisidian text showing apparently non-Greek elements is SEG 57, 1409 (from Sagalassos). The CGRN team are of course aware of these issues: see the "Envoi. The Margins of Greek Ritual Norms", in CARBON - PIRENNE-DELFORGE (2012), p. 180-181.

16. MALAY - PETZL (2017), no. 1. Other candidates have not yet entered CGRN: for a fuller listing see PETROVIC - PETROVIC (2018), p. 228-231.

17. PETROVIC-PETROVIC (2018).

18. See p. 74 above (the passages of Eur. and Dem.); cf. Eur. Alc. 1143-1146.

19. Non-Greek cults on the mainland: e.g. CGRN 155; LSCG 55, and the Marmarini law, in what in BOUCHON -DECOURT (2017), is Face A 27-28. Greek cults outside Greece: not e.g. in CGRN 212 (Athena Nikephoros at Pergamum). Rhodes: LSS 91.16. On this topic see now AUGIER (2017: non vidi). Carbon in a personal communication writes "I am not sure if this partial epigraphic evidence gives us the real picture. In fact, nothing could be more Greek than the expression $\dot{\eta}$ kó $\theta \alpha \rho \sigma \iota \varsigma \tau \tilde{\omega} v$ $\kappa \alpha \tau \alpha \mu \eta v i ́ \omega v$, which is regularly (Aristotle, Hippocrates, Galen, etc.) employed to designate the menses, referring to their full discharge, but also to the time necessary for that to happen and the implicit impurity during this period." But the contrast between the displayed laws from Greek and non-Greek cults would remain even if he were right.

20. At least after contact with death (PARKER [1983], p. 37 n. 17); for birth the case is less clear (PARKER [1983], p. 50 n. 67); even for death CGRN 181.3 (Eresos, late hellenistic) already has 20 days after a relative's death.

21. Lindos: LSS 91.12 (cf. AUGIER [2013]), LSCG 139.18. Prostitutes: MALAY - PETZL (2017) no.1, CGRN 211. PETROVIC - PETROVIC (2018), p. 241 note the clustering on Rhodes of "inner purity" requirements.

22. As argued by DE HOZ (2017).

23. But at Hyllarima apparently just head and feet (CGRN 193).

24. A specificity of naming, not of doing: cf. Ar. Aves 518-519.

25. CGRN 42.3, 104.39, 118.11-12, 14; 119. 9-10.

26. A point stressed to me by Carbon. 
27. But the $\sigma \pi \lambda \alpha$ ó $\gamma \chi$ voput on the hands of statues in Athens (n. 24 above) may ultimately have gone to the priest.

28. BOUCHON - DECOURT (2017), face A, 23-76. The treatment of $\sigma \pi \lambda \alpha ́ \gamma \chi \chi v \alpha$ in the section on sacrifice supposedly "in the Greek manner" (35-43) is typically puzzling: some go to the priestess, some are burned, and there is no mention of distribution among participants.

\section{ABSTRACTS}

This article asks to what extent Greek ritual norms are homogeneous throughout the Greek world. It looks in particular at rules concerning priesthoods, purity and sacrifice. Only the first group displays a clear regional line of division: sale of priesthoods is only attested in the east Greek world, beginning at Andros. That distinction aside, some local singularities or outliers occur in all categories, and some differences that must be due to epigraphic habit. But substantial and regular regional differences at the level of actual ritual practice do not appear. Study of Greek ritual norms may therefore suggest that in some aspects there existed a Greek religion, not just a multitude of locally varying Greek religions.

Dans quelle mesure les normes rituelles grecques sont-elles homogènes dans tout le monde grec ? Pour répondre à cette question, l'article se penche en particulier sur les règles concernant la prêtrise, la pureté et le sacrifice. Une ligne de division régionale n'apparaît clairement que pour le premier groupe : la vente des prêtres n'est attestée que dans le monde grec oriental, à partir d'Andros. Cette distinction mise à part, certaines singularités locales ou exceptions se retrouvent dans toutes les catégories, et certaines différences doivent être imputées à l'habitus épigraphique. Mais des différences régionales substantielles et régulières dans la pratique rituelle effective n'apparaissent pas. L'étude des normes rituelles grecques peut donc suggérer que, sur certains points au moins, il existait une religion grecque, et pas seulement une multitude de religions grecques localement différentes.

\section{AUTHOR}

\section{ROBERT PARKER}

New College, Oxford

robert.parker@new.ox.ac.uk 